\title{
Frequency and expression of mutacin biosynthesis genes in isolates of Streptococcus mutans with different mutacin-producing phenotypes
}

\begin{abstract}
Correspondence
Reginaldo Bruno Gonçalves reginald@fop.unicamp.br
\end{abstract}

Received 4 November 2007

Accepted 23 January 2008

\author{
Regianne Umeko Kamiya, José Francisco Höfling \\ and Reginaldo Bruno Gonçalves
}

\author{
Department of Oral Diagnosis, Microbiology and Immunology Division, Piracicaba Dental School, \\ Campinas University, Piracicaba, SP, Brazil
}

\begin{abstract}
The aim of this study was to analyse the frequency and expression of biosynthesis genes in 47 Streptococcus mutans isolates with different mutacin-producing phenotypes. Detection of the frequency and expression of genes encoding mutacin types I, II, III and IV were carried out by PCR and semi-quantitative RT-PCR, respectively, using primers specific for each type of biosynthesis gene. In addition, a further eight genes encoding putative bacteriocins, designated $\mathrm{bsm} 283$, bsm 299, bsm 423, bsm 1889c, bsm 1892c, bsm 1896, bsm 1906c and bsm 1914, were also screened. There was a high phenotypic diversity; some Streptococcus mutans isolates presented broad antimicrobial spectra against other Streptococcus mutans clinical isolates, including bacteria resistant to common antibiotics, as well as Staphylococcus aureus, Staphylococcus epidermidis, Enterococcus faecalis and Streptococcus pyogenes. The expression frequency of the bsm gene was higher than that of the previously characterized mutacins (I-IV). There was no positive correlation between the number of indicator strains inhibited (antimicrobial spectra) and the number of biosynthesis genes expressed (Spearman correlation test, $r=-0.03, P>0.05$ ). In conclusion, the high diversity of mutacin-producing phenotypes, associated with high frequency of expression of the biosynthesis genes screened, reveals a broad repertoire of genetic determinants encoding antimicrobial peptides that can act in different combinations.
\end{abstract}

\section{INTRODUCTION}

Streptococcus mutans is considered a major aetiological agent of human dental caries due to its capacity for adherence, acid resistance, acidogenicity, resistance to other stress conditions and production of mutacins (Bowden \& Hamilton, 1998; Napimoga et al., 2005). In addition, Streptococcus mutans produces mutacins or antimicrobial peptides that could confer ecological advantage to cariogenic species in diverse bacterial communities such as saliva and dental biofilms (Parrot et al., 1990; Balakrishnan et al., 2002).

In a previous study, we showed that the majority of Streptococcus mutans strains produce mutacin-like substances (Kamiya et al., 2005a); of 319 isolates of Streptococcus mutans isolated from caries-active and caries-free individuals, more than $70 \%$ were able to produce one or more bacteriocin-like substances in vitro. However, the low frequency of biosynthesis genes for mutacins previously characterized in these isolates suggests a high diversity of bacteriocin genetic determinants in Streptococcus mutans (Kamiya et al., 2005b). Despite this

Abbreviation: CSP, competence-stimulating peptide. great diversity, little has been revealed about the biochemical structures of mutacins. In addition, many mutacins have not yet been identified.

Most Streptococcus mutans bacteriocins characterized to date belong to the class I lantibiotics (mutacins I, II, III, 1140, BNy-266, and SmbA and SmbB) (Hillman et al., 1998; Qi et al., 1999a, b, 2000, 2001; Yonezawa \& Kuramitsu, 2005). Class I bacteriocins comprise two subgroups according to their primary peptide sequences (de Vos et al., 1995; Sahl \& Bierbaum, 1998). Subgroup AI contains the nisin-like lantibiotics, as well as subtilin, epidermin, pep5, and mutacins I and III as the most thoroughly characterized members. Subgroup AII consists of lantibiotics including lacticin 481, SA-FF22, salivaricin, variacin and mutacin II (de Vos et al., 1995; Sahl \& Bierbaum, 1998; Qi et al., 2000).

Class II bacteriocins include non-lantibiotics, divided into subclass IIa, which contains the pediocin-like substances, and subclass IIb, which is composed of two synergic peptides (Nes \& Holo, 2000). According to Ajdic et al. (2002), the genome sequence of reference strain Streptococcus mutans UA159 does not possess any genetic determinants that encode lantibiotic mutacins. However, 
other studies have shown that Streptococcus mutans UA159 produces the non-lantibiotic mutacin IV, a non-lantibiotic class IIb bacteriocin encoded by the $n \operatorname{lm} A$ and $n l m B$ genes (Qi et al., 2001), as well as an additional, as-yetunidentified, inhibitory agent (Hale et al., 2005b).

Furthermore, analysis of the Streptococcus mutans genome sequence (Ajdic et al., 2002) has revealed ten small open reading frames with high similarity to the leader peptides of $\mathrm{NlmA}$ and NlmB that encode class IIb bacteriocins (nonlantibiotics), each possessing a double-glycine-type leader sequence similar to that of NlmA and NlmB (Fig. 1) (Hale et al., 2005a; van der Ploeg, 2005). The putative bacteriocins, designated Bsm (bacteriocin Streptococcus mutans), range in size from 47 to 87 aa, have leader peptides of $22-25$ aa and contain a double glycine motif that can be recognized by the ComAB processing and export system (NlmTE). Some of the genes encoding the putative bacteriocins have been found located in tandem, indicating that they might act cooperatively, as is typical for class IIb bacteriocins; these peptides may represent a large repertoire of antimicrobial substances produced by Streptococcus mutans (Hale et al., 2005a; van der Ploeg, 2005).

In the present study, the frequency and expression of characterized mutacin biosynthesis genes was determined, as well as lantibiotics represented by mutacins I, II and III and non-lantibiotic mutacin IV. Additionally, we demonstrated the frequency and expression of the uncharacterized mutacins Bsm 283, Bsm 299, Bsm 423, Bsm 1889c, Bsm 1892c, Bsm 1896, Bsm 1906c and Bsm 1914 in different mutacin-producing Streptococcus mutans phenotypes. The inhibitory spectra were obtained against microbial species of odontological and medical interest.

\section{METHODS}

Strains and Streptococcus mutans isolates. We selected 47 different genotypes of Streptococcus mutans (Sm 1 to Sm 47) for this study; genotypes were isolated from caries-active individuals (Kamiya et al., 2005a), and from caries-free mother-child pairs (Flório et al., 2004; Klein et al., 2004), identified in previous studies.

\section{NlmA \\ Bsm_283 \\ Bsm_299 \\ Bsm_423 \\ Bsm_1889c \\ Bsm_1892c \\ Bsm_1896 \\ Bsm_1906c \\ Bsm_1914 \\ $\mathrm{N} l m \mathrm{~B}$}

For mutacin activity testing and phenotyping, the following 16 Streptococcus spp. were used as indicator strains: Streptococcus mutans UA159, Streptococcus mutans UA130, Streptococcus mutans CCT 3440, Streptococcus mutans 32K, Streptococcus sobrinus ATCC 27607, Streptococcus sobrinus 6715, Streptococcus mitis A, Streptococcus mitis ATCC 903, Streptococcus salivarius ATCC 25975, Streptococcus salivarius 66.4, Streptococcus sanguinis CR311, Streptococcus sanguinis M5, Streptococcus sanguinis ATCC 10556, Streptococcus sanguinis ATCC 15300, Streptococcus oralis PB182 and Streptococcus criceti HS6. In addition, 14 Streptococcus mutans isolates were used in the test as indicator strains.

Sixteen high inhibitory spectra mutacin-producing isolates were selected and submitted to an antagonism method against nine bacterial and five fungal species, comprising: Enterococcus faecalis ATCC 10100, Enterococcus faecalis ATCC 14506, Enterococcus faecalis ATCC $19433^{\mathrm{T}}$, Enterococcus faecalis ATCC 29212, Staphylococcus aureus ATCC 6538DR, Staphylococcus aureus ATCC 12692, Staphylococcus aureus ATCC 19095, Staphylococcus aureus ATCC 27664, Staphylococcus epidermidis ATCC 12228, Streptococcus pyogenes ATCC 8668 (A group), Streptococcus pyogenes ATCC $12344^{\mathrm{T}}$, Streptococcus pyogenes ATCC 19615, Streptococcus gordonii Chalis, Lactobacillus casei L324M, Lactobacillus acidophilus A, Pseudomonas aeruginosa ATCC 25619, Escherichia coli NCTC 8196, Candida albicans ATCC 36801, C. albicans ATCC 36802, C. albicans CBS 562, Candida dubliniensis CBS 7987, Candida krusei CBS 573, Candida parapsilosis CBS 604 and Candida tropicalis CBS 94. Additionally, mutacin-producing Streptococcus mutans $(n=16)$ were also used as indicator strains.

Antagonism method. The genotypes of Streptococcus mutans were characterized as producers of mutacin-like substances by the antagonism method, as described previously by our group with some modifications (Kamiya et al., 2005a). Briefly, frozen Streptococcus mutans cultures were reactivated in $5 \mathrm{ml}$ brain heart infusion broth (Difco) and incubated at $37{ }^{\circ} \mathrm{C}$ with $10 \% \mathrm{CO}_{2}$ for $12 \mathrm{~h}$. The strain cultures $\left(\sim 10^{8}\right.$ c.f.u. $\mathrm{ml}^{-1}$, measured at $\left.\mathrm{OD}_{550}\right)$ were inoculated equidistantly in $1.5 \%(\mathrm{w} / \mathrm{v})$ trypticase soy agar (TSA; Difco) using a $0.6 \mathrm{~mm}$ needle. After a $48 \mathrm{~h}$ incubation at $37{ }^{\circ} \mathrm{C}$ and $10 \% \mathrm{CO}_{2}$, the plates were overlaid with $4.5 \mathrm{ml}$ soft $0.8 \%(\mathrm{w} / \mathrm{v})$ TSA containing $0.5 \mathrm{ml}$ of an overnight trypticase soy broth (TSB; Difco) culture $\left(\sim 10^{8}\right.$ c.f.u. $\mathrm{ml}^{-1}$ ) of the indicator strain. After overnight incubation at $37{ }^{\circ} \mathrm{C}$, the diameter of the inhibition zones was measured. The isolates were recorded as mutacin active against the indicator strain if the diameter was $6 \mathrm{~mm}$ or greater (Wu et al., 2004). The isolates were tested in duplicate for mutacin activity.

Mutacin activity profiles. Thirty Streptococcus spp. indicator strains were used. For every three indicator strains, a score of between 0 and 7 was given to the isolates depending on which of the isolates were sensitive to the mutacin produced (Table 1). In this way, a ten-figure profile characterized every isolate. These profiles were regarded as distinct when one or more of the figures were different (van Loveren et al., 2000).

Kirk-Bauer disc diffusion method. Bacterial indicator strains of medical interest, as well as Staphylococcus aureus, Staphylococcus epidermidis, Enterococcus faecalis and Streptococcus pyogenes, were submitted to the Kirk-Bauer disc diffusion method, which was performed in accordance with Clinical and Laboratory Standards Institute standards (CLSI, 2006). The antimicrobials used were: benzylpenicillin, ampicillin, amoxicillin, imipinem, vancomycin, azithromycin, streptomycin and tetracycline. The bacterial strains Staphylococcus aureus ATCC 25923, Escherichia coli ATCC 25922 and P. aeruginosa ATCC 27853 were used as quality controls for the discs (Laborclin).

PCR screening of mutacin genes. Total DNA was extracted using a Master Pure DNA Purification kit (Epicentre Biotechnologies),
Fig. 1. CLUSTAL $W$ sequence alignment of NImA and NImB (the pre-peptides of the two-component non-lantibiotic mutacin IV) with other pre-peptides (in Streptococcus mutans UA159) containing the double-glycine motif. Adapted from Hale et al. (2005b) and van der Ploeg (2005). 
Table 1. System used to transform the bacteriocin production against three indicator strains into a unique numerical classification (van Loveren et al., 2000)

+ , Bacteriocin production against indicator strains; -, no bacteriocin production against indicator strains.

\begin{tabular}{|lccc|}
\hline Score & \multicolumn{3}{c|}{ Indicator strain } \\
\cline { 2 - 4 } & $\mathbf{1}$ & $\mathbf{2}$ & $\mathbf{3}$ \\
\hline 0 & - & - & - \\
1 & + & - & - \\
2 & - & + & - \\
3 & + & + & - \\
4 & - & - & + \\
5 & + & - & + \\
6 & - & + & + \\
7 & + & + & + \\
\hline
\end{tabular}

according to the manufacturer's instructions. The mutacin-producing strains were grown in $3 \mathrm{ml}$ brain heart infusion broth (Oxoid) for $18 \mathrm{~h}$ at $37{ }^{\circ} \mathrm{C}$ and $10 \% \mathrm{CO}_{2}$. Aliquots of $1.5 \mathrm{ml}$ culture were submitted to centrifugation ( $13000 \mathrm{~g}$ at $4{ }^{\circ} \mathrm{C}$ for $5 \mathrm{~min}$ ) and DNA was extracted from the pellet. The DNA purity was determined by calculating the $A_{260} / A_{280}$ ratio.
The detection of biosynthesis genes encoding mutacin types I, II, III and IV (Qi et al., 1999a, b, 2001) and different bsm genes was performed by PCR using primers specific to each type of gene. Primers for the genes encoding mutacins or bacteriocins were designed based on sequences obtained from GenBank (http:// www.ncbi.nlm.nih.gov) (Table 2) using the Primer3 program (http://frodo.wi.mit.edu/cgi-bin/primer3/primer3_www.cgi).

PCR amplification was performed using a GeneAmp PCR System 2400 (Perkin Elmer). The $50 \mu \mathrm{l}$ reactions consisted of $1 \times$ PCR buffer containing $2.5 \mathrm{mM} \mathrm{MgCl} 2,200 \mu \mathrm{M}$ each dNTP, $0.3 \mu \mathrm{M}$ each oligonucleotide primer, 1.25 U Taq DNA polymerase (Life Technologies) and $50 \mathrm{ng}$ template DNA. In addition to the strains being tested, purified genomic DNA from Streptococcus mutans UA159 was used as a positive control for mutacin gene type IV and bsm genes. Distilled water was used as a negative control in each PCR.

The PCR conditions were optimized using, as controls, DNA from Streptococcus mutans UA159 and the clinical isolate carrier mutAI, mutAII and mutAIII genes (detected in a previous study; Kamiya et al., 2005b). The PCR conditions comprised initial denaturation at $94{ }^{\circ} \mathrm{C}$ for $5 \mathrm{~min}$, followed by 35 cycles of denaturation at $94{ }^{\circ} \mathrm{C}$ for $45 \mathrm{~s}$, annealing at $50{ }^{\circ} \mathrm{C}$ for $1 \mathrm{~min}$ and extension at $72{ }^{\circ} \mathrm{C}$ for $2 \mathrm{~min}$, with a final extension at $72{ }^{\circ} \mathrm{C}$ for $7 \mathrm{~min}$. The PCR products were analysed by electrophoresis in a $1.0 \%$ agarose gel stained with $0.3 \mathrm{mg}$ ethidium bromide $\mathrm{ml}^{-1}$. A $100 \mathrm{bp}$ DNA ladder was included in each gel.

RNA extraction, synthesis of CDNA and semi-quantitative RTPCR. Mutacin-producing strains that were shown to have the screened structural genes by PCR were submitted to RNA extraction

Table 2. PCR and RT-PCR primers of mutacins I-IV and the bsm genes

\begin{tabular}{|c|c|c|c|c|}
\hline Protein & Primer & Primer sequences & GenBank accession no. & Amplicon (bp) \\
\hline \multirow[t]{2}{*}{ Mutacin I (MutAI) } & mutAI_F & TAGAAGTCCTTGGTACTGAA & AF238860 & 163 \\
\hline & mutAI_R & TTGAAACTAGGATTTTTCAC & & \\
\hline \multirow[t]{2}{*}{ Mutacin II (MutAII) } & mutAII_F & CAGTAACGCAGTAGTTCCTT & U40620 & 162 \\
\hline & mutAII_R & TTAACAGCAAGTGAAAACAT & & \\
\hline \multirow[t]{2}{*}{ Mutacin III (MutAIII) } & mutAIII_F & CAATTATTAGAAGTCCTTGG & AF154675 & 194 \\
\hline & mutAIII_R & TATTGAAACTACCTGTCCTT & & \\
\hline \multirow[t]{2}{*}{ Mutacin IV (NlmA) } & nlmA_F & CAATTTGATGTAATGGACAG & NC_004350* & 154 \\
\hline & nlmA_R & CTACACAATATGGGGTAACA & & \\
\hline \multirow[t]{2}{*}{ Mutacin IV (NlmB) } & nlmB_F & AGTTTTGGTGGAGATAAAC & NC_004350* & 156 \\
\hline & nlmB_R & GGAAAAACTACAGATCCAA & & \\
\hline \multirow[t]{2}{*}{ Bsm_283 } & Bsm_283F & GCTAGTATTGAGGGAGGAT & NC_004350* & 153 \\
\hline & Bsm_283R & ATAAATAACTGCAGCACCT & & \\
\hline \multirow[t]{2}{*}{ Bsm_299 } & Bsm_299F & AAACTATGGATGCTGAAAC & NC_004350* & 160 \\
\hline & Bsm_299R & GAAGCCCAGCTATTTACTA & & \\
\hline \multirow[t]{2}{*}{ Bsm_423 } & Bsm_423F & GTAATGGATAATGAAGCAC & NC_004350* & 154 \\
\hline & Bsm_423R & CAGATACTGTACCAACGAC & & \\
\hline \multirow[t]{2}{*}{ Bsm_1889c } & Bsm_1889cF & GCTCCTGATATAGCTCCTA & NC_004350* & 154 \\
\hline & Bsm_1889cR & AATGTATTGTAGGGACAGG & & \\
\hline \multirow[t]{2}{*}{ Bsm_1892c } & Bsm_1892cF & CGAGCATAGCTTACAACT & NC_004350* & 130 \\
\hline & Bsm_1892cR & CACAAACTGAAATCTGGA & & \\
\hline \multirow[t]{2}{*}{ Bsm_1896 } & Bsm_1896F & GTATCTGGAGAGGTTTCAA & NC_004350* & 148 \\
\hline & Bsm_1896R & ACACCAGCTCCTGATATAC & & \\
\hline \multirow[t]{2}{*}{ Bsm_1906 } & Bsm_1906F & CTATTCCAAGGACTCCAC & NC_004350* & 140 \\
\hline & Bsm_1906R & ACGTCATGGATAGTCAAGT & & \\
\hline \multirow[t]{2}{*}{ Bsm_1914c } & Bsm_1914cF & AATAGCATATGGACCAAGA & NC_004350* & 141 \\
\hline & Bsm_1914cR & ACGTAATGGATAATGAAGC & & \\
\hline
\end{tabular}

${ }^{\star}$ Based on the Streptococcus mutans UA159 genome. 
Table 3. Antimicrobial activities of the mutacin-producing phenotypes $(n=47)$ against 30 Streptococcus sp. indicator strains

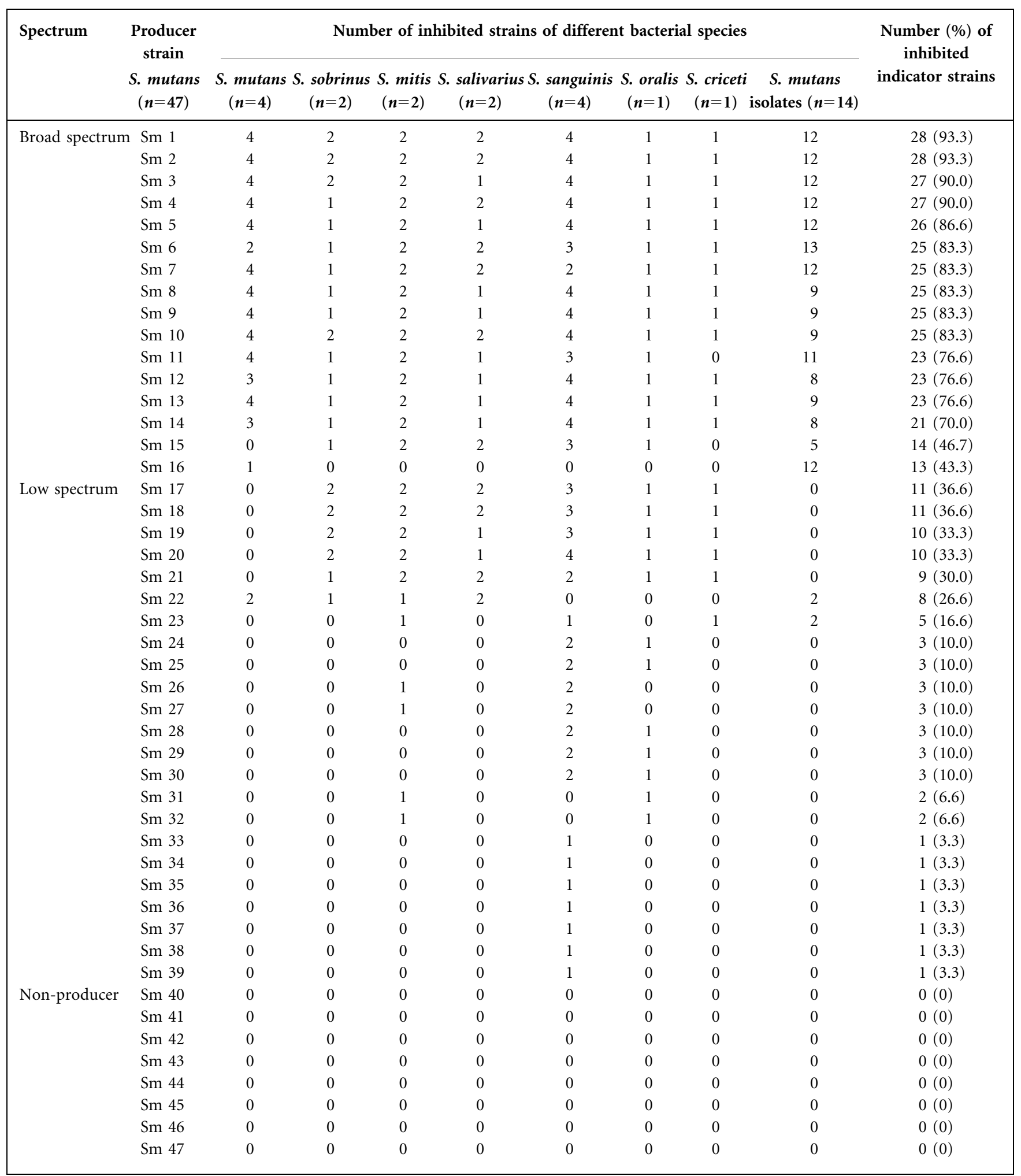

and a semi-quantitative RT-PCR technique to verify the possible expression of these genes. The strains were grown in $40 \mathrm{ml}$ TSB at $37{ }^{\circ} \mathrm{C}, 10 \% \mathrm{CO}_{2}$, up to the final exponential phase at $10-12 \mathrm{~h}$. The planktonic cells were obtained by centrifugation and submitted to RNA extraction using a phenol/chloroform method (Qi et al., 1999a).
Residual DNA in the extracted RNA was removed with DNase I (Gibco), according to the manufacturer's instructions. cDNA synthesis was performed with $24 \mathrm{ng}$ total RNA using a random primer mix of Ea1, Ea7, Es1, Es3 and Es8 (Chia et al., 2001) and the enzyme SuperScript III reverse transcriptase (Gibco), following the 
Table 4. Antimicrobial activity of the broad-spectrum mutacin-producing phenotypes $(n=16)$ against 36 indicator strains

\begin{tabular}{|c|c|c|c|c|c|c|c|c|}
\hline \multirow{2}{*}{$\begin{array}{l}\text { Producer } \\
\text { strain }(n=16)\end{array}$} & \multicolumn{7}{|c|}{ Number of inhibited strains of different bacterial and fungi species } & \multirow{2}{*}{$\begin{array}{c}\text { Total no. (\%) of } \\
\text { inhibited } \\
\text { indicator strains }\end{array}$} \\
\hline & $\begin{array}{l}\text { Lactobacillus } \\
\text { spp. }(n=2)\end{array}$ & $\begin{array}{l}\text { Staphylococcus } \\
\text { aureus }(n=4)\end{array}$ & $\begin{array}{l}\text { Staphylococcus } \\
\text { epidermidis } \\
\quad(n=1)\end{array}$ & $\begin{array}{l}\text { Streptococcus } \\
\text { pyogenes } \\
(n=3)\end{array}$ & $\begin{array}{l}\text { Enterococcus } \\
\text { faecalis } \\
(n=3)\end{array}$ & $\begin{array}{c}\text { Streptococcus } \\
\text { mutans producer } \\
\text { strains }(n=16)\end{array}$ & $\begin{array}{l}\text { Candida } \\
\text { spp. } \\
(n=7)\end{array}$ & \\
\hline Sm 1 & 2 & 4 & 1 & 3 & 0 & 14 & 5 & $29(80.5)$ \\
\hline Sm 2 & 2 & 4 & 1 & 3 & 0 & 14 & 5 & $29(80.5)$ \\
\hline Sm 3 & 1 & 2 & 0 & 3 & 2 & 1 & 0 & $9(25.0)$ \\
\hline Sm 4 & 2 & 4 & 1 & 3 & 1 & 7 & 5 & $23(63.8)$ \\
\hline Sm 5 & 2 & 4 & 1 & 3 & 0 & 15 & 3 & $28(77.7)$ \\
\hline Sm 6 & 1 & 4 & 1 & 3 & 2 & 15 & 2 & $28(77.7)$ \\
\hline Sm 7 & 1 & 1 & 0 & 3 & 0 & 2 & 0 & $7(19.4)$ \\
\hline Sm 8 & 2 & 4 & 1 & 3 & 1 & 12 & 5 & $28(77.7)$ \\
\hline Sm 9 & 2 & 4 & 1 & 3 & 0 & 11 & 2 & $23(63.8)$ \\
\hline Sm 10 & 2 & 4 & 1 & 3 & 1 & 1 & 3 & $15(41.6)$ \\
\hline Sm 11 & 2 & 4 & 1 & 3 & 0 & 15 & 5 & $30(83.3)$ \\
\hline Sm 12 & 2 & 4 & 1 & 3 & 0 & 15 & 4 & $29(80.5)$ \\
\hline Sm 13 & 1 & 1 & 0 & 3 & 2 & 0 & 0 & $7(19.4)$ \\
\hline Sm 14 & 2 & 4 & 1 & 3 & 0 & 14 & 4 & $28(77.7)$ \\
\hline Sm 15 & 1 & 0 & 0 & 2 & 0 & 0 & 0 & $3(8.3)$ \\
\hline Sm 16 & 0 & 0 & 0 & 3 & 0 & 7 & 0 & $10(27.7)$ \\
\hline
\end{tabular}

manufacturer's protocol, with some modifications. The reaction mix contained the total RNA, $20 \mu \mathrm{M}$ random primer mix, $10 \mathrm{mM}$ dNTPs and DEPC-treated $\mathrm{H}_{2} \mathrm{O}$ to $10 \mu$. The solution was heated at $65{ }^{\circ} \mathrm{C}$ for $5 \mathrm{~min}$ and cooled at $4{ }^{\circ} \mathrm{C}$ for $1 \mathrm{~min}$. The following were then added to the reaction mixture (final concentrations): $1 \times$ RT buffer, $25 \mathrm{mM}$ $\mathrm{MgCl}_{2}, 0.1 \mathrm{M}$ DTT, $40 \mathrm{U}$ RNase OUT and $200 \mathrm{U}$ SuperScript III reverse transcriptase, and the total volume of $20 \mu \mathrm{l}$ containing the cDNA was submitted to the following thermal cycle: $25{ }^{\circ} \mathrm{C}$ for $10 \mathrm{~min}, 50{ }^{\circ} \mathrm{C}$ for $50 \mathrm{~min}, 85^{\circ} \mathrm{C}$ for $5 \mathrm{~min}$ and $4{ }^{\circ} \mathrm{C}$ for $1 \mathrm{~min}$. For each RNA sample, the cDNA synthesis reaction was also carried out without reverse transcriptase to identify contamination by residual genomic DNA. For maximum efficiency, the RT-PCR primers were designed to generate amplicons ranging from 130 to $200 \mathrm{bp}$ (Table 2).

A $1 \mu \mathrm{l}$ volume of cDNA was used as template in the PCR (total volume $25 \mu \mathrm{l}$ ) containing $50 \mathrm{mM} \mathrm{MgCl}_{2}, 0.3 \mathrm{mM}$ each specific primer (Table 2), $200 \mu \mathrm{M}$ dNTPs, $1.25 \mathrm{U}$ Taq DNA polymerase (Gibco) and $1 \times$ PCR buffer. All samples of cDNA were tested with primers for the $16 \mathrm{~S}$ rRNA gene, a constitutively transcribed control gene whose expression is invariant under the experimental conditions used. The primer set $16 \mathrm{~S} /$ forward (5'-CGGCAAGCTAATCTCTGAAA- $3^{\prime}$ ) and 16S/reverse (5'-GCCCCTAAAAGGTTACCTCA-3') was designed based on the Streptococcus mutans UA159 genome (GenBank accession no. NC_004350). Controls for the RT-PCR included reaction mixtures without template $\mathrm{cDNA}$ to rule out the presence of contaminating DNA and/or the formation of primer dimers.

The amplicons were visualized on a $2 \%$ agarose gel stained with ethidium bromide $\left(0.3 \mathrm{mg} \mathrm{ml}^{-1}\right)$. The positive controls and a $100 \mathrm{bp}$ DNA ladder were included in each gel.

\section{RESULTS AND DISCUSSION}

In the present study, about $83 \%$ (39/47) of the Streptococcus mutans strains analysed showed mutacin activity against one or more of the indicator strains (Table 3). Mutacin production frequency in Streptococcus mutans can vary from 70 to $100 \%$ depending on the conditions of the tests and the indicator strains used (Rogers et al., 1979). The inhibition zone sizes for producer strains varied from 6 to $30 \mathrm{~mm}$ in diameter. On average, $34.1 \%(16 / 47)$ of these isolates presented a broad spectrum, inhibiting more than $43 \%$ of the indicator strains of Streptococcus spp., including Streptococcus mutans isolates, and $48.9 \%(23 / 47)$ presented a low spectrum, inhibiting from 3 to $36 \%$ of the indicator strains of Streptococcus spp. (Table 3).

Some mutacin-like substances presented broad antimicrobial spectra. These inhibitory substances were able to kill or inhibit the growth of indicator strains of medical interest that are resistant to some commonly used antibiotics, as well as Enterococcus faecalis, Streptococcus pyogenes, Staphylococcus aureus and Staphylococcus epidermidis (Tables 4 and 5). These results emphasize the importance of mutacins in future pharmacology applications, although more studies are necessary to determine their use as a safe antimicrobial agent. There was no antimicrobial activity against Streptococcus gordonii and Gram-negative bacteria, as well as P. aeruginosa and Escherichia coli.

As shown in Fig. 2, of the characterized mutacins, the most frequent biosynthesis gene among the isolates was mutAI (29.1\%), although the $n \operatorname{lm} A$ and $n \operatorname{lm} B$ genes were more highly expressed in mutacin IV $(18.7 \%)$. Five broadspectrum isolates and one low-spectrum strain produced mutacin type III. The low frequency of genetic determinants of the characterized mutacins detected in this study is consistent with previous studies (Longo et al., 2003; Kamiya et al., 2005b). On the other hand, some phenotypes presented amplicons and positive gene expression for 
Table 5. Susceptibility profiles of the indicator strains of medical interest to some commonly used antibiotics

Results were obtained using the Kirk-Bauer disc diffusion method. Nomenclature based on CLSI recommendations: S, sensitive; MS, moderately sensitive; I, intermediate; R, resistant.

\begin{tabular}{|c|c|c|c|c|c|c|c|c|c|c|}
\hline \multirow{2}{*}{$\begin{array}{l}\text { Indicator strain of } \\
\text { medical interest }(n=14)\end{array}$} & \multicolumn{8}{|c|}{ Common antibiotics } & \multicolumn{2}{|c|}{ Mutacin activities } \\
\hline & $\begin{array}{l}\text { Penicillin } \\
\quad(10 \mathrm{U})\end{array}$ & $\begin{array}{l}\text { Ampicillin } \\
\quad(10 \mu \mathrm{g})\end{array}$ & $\begin{array}{l}\text { Amoxicillin } \\
\quad(10 \mu \mathrm{g})\end{array}$ & $\begin{array}{l}\text { Imipinem } \\
(10 \mu \mathrm{g})\end{array}$ & $\begin{array}{l}\text { Vancomycin } \\
(30 \mu \mathrm{g})\end{array}$ & $\begin{array}{l}\text { Azithromycin } \\
\qquad(15 \mu \mathrm{g})\end{array}$ & $\begin{array}{l}\text { Streptomycin } \\
\quad(10 \mu \mathrm{g})\end{array}$ & $\begin{array}{l}\text { Tetracycline } \\
\quad(30 \mu \mathrm{g})\end{array}$ & $\begin{array}{l}\text { No. }(\%) \text { of } \\
\text { mutacin-producing } \\
\text { strains with } \\
\text { inhibitory activity }\end{array}$ & $\begin{array}{c}\text { Mean } \pm \text { SD of } \\
\text { inhibition zone } \\
\quad(\mathrm{mm})\end{array}$ \\
\hline Enterococcus faecalis ATCC 10100 & $\mathrm{R}$ & MS & $\mathrm{R}$ & I & I & $\mathrm{R}$ & $\mathrm{R}$ & I & $6(37.5)$ & $(6.3 \pm 0.8)$ \\
\hline Enterococcus faecalis ATCC 14506 & $\mathrm{R}$ & $\mathrm{R}$ & $\mathrm{R}$ & S & $\mathrm{R}$ & $\mathrm{R}$ & $\mathrm{R}$ & $\mathrm{R}$ & 0 & - \\
\hline Enterococcus faecalis ATCC $19433^{\mathrm{T}}$ & $\mathrm{R}$ & $\mathrm{R}$ & $\mathrm{R}$ & S & $\mathrm{R}$ & $\mathrm{R}$ & $\mathrm{R}$ & $\mathrm{R}$ & 0 & - \\
\hline Enterococcus faecalis ATCC 29212 & $\mathrm{R}$ & $\mathrm{R}$ & $\mathrm{R}$ & S & $\mathrm{R}$ & $\mathrm{R}$ & $\mathrm{R}$ & $\mathrm{R}$ & $3(18.7)$ & $(6.0 \pm 0.0)$ \\
\hline Streptococcus pyogenes ATCC 8668 & $\mathrm{R}$ & $\mathrm{S}$ & S & S & S & $\mathrm{R}$ & $\mathrm{R}$ & S & $15(93.7)$ & $(11.0 \pm 2.7)$ \\
\hline Streptococcus pyogenes ATCC $12344^{\mathrm{T}}$ & $\mathrm{R}$ & $\mathrm{R}$ & $\mathrm{R}$ & S & S & $\mathrm{R}$ & $\mathrm{R}$ & $\mathrm{R}$ & $16(100)$ & $(20.0 \pm 0.0)$ \\
\hline Streptococcus pyogenes ATCC 19615 & S & S & S & S & $\mathrm{R}$ & $\mathrm{R}$ & $\mathrm{R}$ & I & $16(100)$ & $(20.0 \pm 0.0)$ \\
\hline Staphylococcus aureus ATCC 19095 & $S$ & S & $S$ & $S$ & I & $\mathrm{R}$ & $\mathrm{R}$ & $\mathrm{R}$ & $11(68.7)$ & $(13.2 \pm 1.8)$ \\
\hline Staphylococcus aureus ATCC 27664 & S & S & S & S & I & $\mathrm{R}$ & $\mathrm{R}$ & $\mathrm{R}$ & $12(75.0)$ & $(12.0 \pm 2.4)$ \\
\hline Staphylococcus epidermidis ATCC 12228 & $\mathrm{R}$ & $\mathrm{R}$ & $\mathrm{R}$ & S & S & $\mathrm{R}$ & $\mathrm{R}$ & $\mathrm{R}$ & $11(68.7)$ & $(13.6 \pm 0.8)$ \\
\hline P. aeruginosa ATCC 25619 & $\dagger$ & I & $\mathrm{R}$ & S & $\mathrm{R}$ & $\mathrm{R}$ & $\mathrm{R}$ & $\mathrm{R}$ & 0 & - \\
\hline E. coli NCTC 8196 & $\dagger$ & $\mathrm{R}$ & $\mathrm{R}$ & $S$ & $\mathrm{R}$ & $\mathrm{R}$ & S & S & 0 & - \\
\hline
\end{tabular}

${ }^{*}$ Inhibitory activity detected by the antagonism method (inhibition diameters varied between 6 and $20 \mathrm{~mm}$ ).

$\dagger$ No nomenclature. 


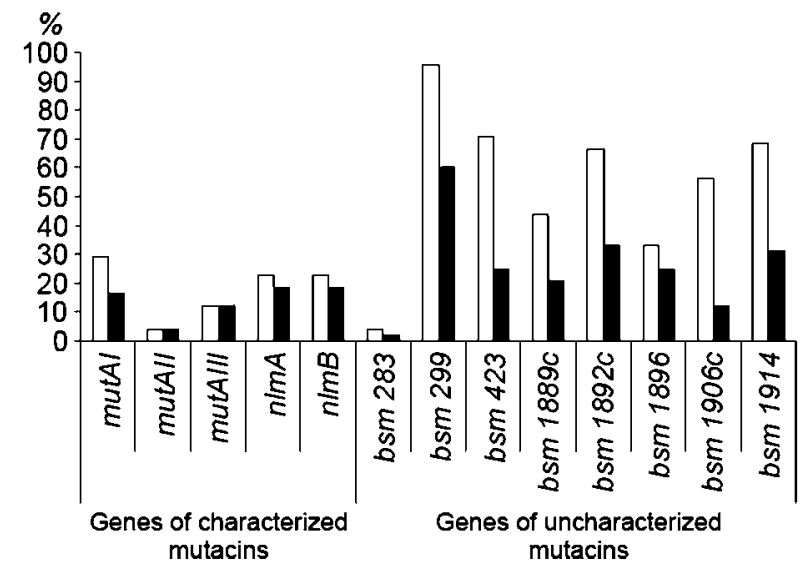

Fig. 2. Frequency $(\square)$ and expression ( $\boldsymbol{\square}$ ) of genes encoding characterized and uncharacterized mutacins (bsm genes) in Streptococcus mutans isolates.

mutacins I, II, III and IV, but did not reveal the same antimicrobial spectra. One possible explanation is that the modification of only one amino acid has been shown previously to alter or eliminate the activity of certain bacteriocins (Rollema et al., 1995; Chan et al., 1996). Furthermore, possible polymorphisms of biosynthesis genes or in the cluster of genes related to mutacin production may account for differences in virulence among Streptococcus mutans strains. In addition, the inhibition zone could also result from the production of more than one inhibitory substance.

Mutacin IV was produced by $17 \%$ of isolates $(n=8)$, although it presented low antimicrobial spectra with activity mainly against initial colonizers, as well as Streptococcus sanguinis and Streptococcus oralis. In contrast, Hale et al. (2005a) demonstrated the broad antimicrobial spectra of mutacin IV produced by Streptococcus mutans UA159 against a panel of 84 mutacin-sensitive indicator bacteria consisting of 74 streptococcal strains, eight strains of Lactococcus lactis and two strains of Micrococcus luteus. The differences between the method and indicator strains used hinder a comparison of the results.

Mutacin IV is encoded by the $n \operatorname{lm} A$ and $n \operatorname{lm} B$ genes, which are probably organized in an operon (Qi et al., 2001). Genetic dissection of the $n \operatorname{lm} A B$ locus does not support the hypothesis that mutacin IV is a two-component mutacin and thus the role, if any, of $\mathrm{NlmB}$ remains enigmatic (Hale et al., 2005a). In our study, two strains showed expression of $n \operatorname{lm} A$ or $n \operatorname{lm} B$ and distinct phenotypic profiles (Table 6). The individual roles of NlmA and NlmB in mutacin IV activity could not be identified in the present study.

Recently, analysis of the Streptococcus mutans genome sequence revealed ten small open reading frames that could encode class II bacteriocins (Hale et al., 2005a; van der Ploeg, 2005). In the present study, the bsm genes of the uncharacterized mutacins were more frequent than the characterized mutacin genes in Streptococcus mutans. The frequencies varied between 4 and $95 \%$ and the gene expression varied between 2 and $60 \%$ among clinical isolates (Fig. 2). The genes bsm 299 and bsm $1892 c$ were more frequently expressed in relation to other bacteriocins. These findings suggest that all putative bacteriocins may represent a large repertoire of inhibitory substances produced by Streptococcus mutans. According to van der Ploeg (2005), different combinations of bacteriocins have different antimicrobial spectra.

The clinical isolates expressed between one and seven mutacin biosynthesis genes and were able to inhibit between one and 28 Streptococcus spp. indicator strains. There was no association between the mutacin inhibitory spectrum and the number of expressed biosynthesis genes (Spearman correlation test $r=-0.03 ; P>0.05)$. In addition, nomutacin-producing strains expressed between one and four bsm genes (Table 6). These results raise several questions: (i) Under what conditions are bsm and the characterized mutacin biosynthesis genes expressed and active? (ii) How are they regulated? (iii) How are they secreted?

Gene expression does not imply protein activity. For example, genetic mutations not identified here may modify the proteins and their activities. Low gene expression may hinder protein detection, as at lower levels there will be insufficient antimicrobial activity of the protein and little diffusion in the antagonism assay. However, it is possible that the range of indicator strains selected for this study may not have been sufficiently diverse to detect any activity conferred by different Bsm proteins.

On the other hand, the regulatory or transport mechanisms of these peptides may be defective. Recently, Kreth et al. (2006) showed that a group of bacteriocin-like genes ( $\mathrm{bsm}$ 423, bsm $1906 c$ and bsm 1914c) together with $n \operatorname{lm} A$ responded strongly to competence-stimulating peptide (CSP) addition, increasing transcription up to 30 -fold, suggesting that these genes may form a CSP regulon mediated by the comDE two-component regulatory system. Furthermore, according to van der Ploeg (2005), some Bsm proteins depend on transport proteins (ComDE) that also carry the CSP peptide. The presence of this highly conserved region indicates that the expression of these bacteriocin-encoding $(\mathrm{bsm})$ genes is under coordinated control by the comDE two-component signal transduction system. Another probable transport mechanism, corresponding to NlmTE (ComAB), the $n l m T$-deficient mutant, $\Delta \mathrm{NlmT}$, failed to express any inhibitory activity, indicating that the NlmTE ABC transporter is also required for nonlantibiotic export (Hale et al., 2005b).

The phenotypic grouping was not identical to the genotypic grouping. Genotypes with the same qualitative genetic expression profiles did not present the same mutacin production profiles, and distinct genotypes were grouped in the same phenotypic profile of production, showing that the patterns of inhibitory spectra produced by distinct 
Table 6. Analysis of expression of biosynthesis genes of mutacins I-IV and Bsm in different bacteriocin-producing phenotypes Shaded squares, positive expression; open squares, negative expression. Letters from A to Z correspond to the 24 phenotypes (mutacin types).

\begin{tabular}{|c|c|c|c|c|c|c|c|c|c|c|c|c|c|c|c|c|c|c|}
\hline \multirow[b]{2}{*}{ 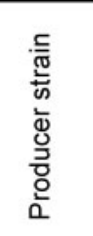 } & \multicolumn{13}{|c|}{ Genotypic profiles based on expressed genes } & \multirow[b]{2}{*}{ 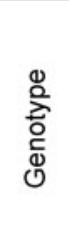 } & \multirow{2}{*}{ 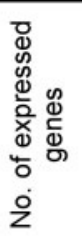 } & \multirow{2}{*}{ 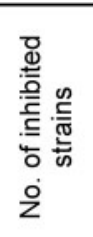 } & \multirow{2}{*}{ 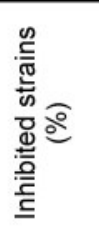 } & \multirow[b]{2}{*}{$\begin{array}{l}\text { Phenotypes based on } \\
\text { mutacin typing }\end{array}$} \\
\hline & ฟิ & है & ह & ह & है & 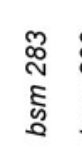 & $\begin{array}{l}\text { 尺े } \\
\text { हू } \\
\text { S }\end{array}$ & 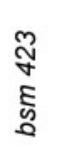 & 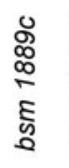 & 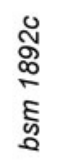 & 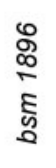 & $\begin{array}{l}\mathscr{8} \\
\stackrel{8}{\circ} \\
\stackrel{5}{5} \\
\text { ह }\end{array}$ & 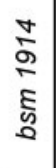 & & & & & \\
\hline Sm 12 & & & & & & & & & & & & & & \multirow{8}{*}{1} & 0 & 23 & 76.6 & {$[7237711357](P)$} \\
\hline $\operatorname{Sm} 13$ & & & & & & & & & & & & & & & 0 & 23 & 76.6 & {$[7576734477](U)$} \\
\hline Sm 14 & & & & & & & & & & & & & & & 0 & 21 & 68.9 & {$[7237711357](P)$} \\
\hline Sm 16 & & & & & & & & & & & & & & & 0 & 13 & 43.3 & {$[2000027377](M)$} \\
\hline Sm 31 & & & & & & & & & & & & & & & 0 & 2 & 6.6 & {$[0020400000](E)$} \\
\hline Sm 32 & & & & & & & & & & & & & & & 0 & 2 & 6.6 & {$[0020400000](E)$} \\
\hline Sm 42 & & & & & & & & & & & & & & & 0 & 0 & 0 & {$[0000000000](A)$} \\
\hline $\operatorname{Sm} 43$ & & & & & & & & & & & & & & & 0 & 0 & 0 & {$[0000000000](A)$} \\
\hline Sm 1 & & & & & & & & & & & & & & \multirow{3}{*}{2} & 1 & 28 & 93.3 & {$[7777755777](Z)$} \\
\hline $\mathrm{Sm} 2$ & & & & & & & & & & & & & & & 1 & 28 & 93.3 & [7777755777] (Z) \\
\hline $\mathrm{Sm} 4$ & & & & & & & & & & & & & & & 1 & 27 & 89.6 & {$[7377755777](T)$} \\
\hline Sm 18 & & & & & & & & & & & & & & \multirow{3}{*}{3} & 1 & 11 & 36.6 & {$[0377510000](\mathrm{J})$} \\
\hline Sm 41 & & & & & & & & & & & & & & & 1 & 0 & 0 & {$[0000000000](A)$} \\
\hline Sm 46 & & & & & & & & & & & & & & & 1 & 0 & 0 & {$[0000000000](A)$} \\
\hline Sm 23 & & & & & & & & & & & & & & \multirow{3}{*}{4} & 1 & 5 & 16.6 & {$[0020100110](D)$} \\
\hline $\mathrm{Sm} 33$ & & & & & & & & & & & & & & & 1 & 1 & 3.3 & {$[0000200000](B)$} \\
\hline Sm 34 & & & & & & & & & & & & & & & 1 & 1 & 3.3 & {$[0000200000](B)$} \\
\hline Sm 6 & & & & & & & & & & & & & & 5 & 1 & 25 & 83.3 & {$[3277667377](0)$} \\
\hline Sm 37 & & & & & & & & & & & & & & 6 & 2 & 1 & 3.3 & {$[0000200000](B)$} \\
\hline Sm 22 & & & & & & & & & & & & & & 7 & 2 & 8 & 26.6 & {$[2351000110](\mathrm{N})$} \\
\hline Sm 7 & & & & & & & & & & & & & & \multirow{2}{*}{8} & 2 & 25 & 83.3 & {$[7377555777](T)$} \\
\hline Sm 17 & & & & & & & & & & & & & & & 2 & 11 & 36.6 & {$[0377510000](\mathrm{J})$} \\
\hline Sm 47 & & & & & & & & & & & & & & 9 & 2 & 0 & 0 & {$[0000000000](A)$} \\
\hline Sm 44 & & & & & & & & & & & & & & 10 & 2 & 0 & 0 & {$[0000000000](A)$} \\
\hline Sm27 & & & & & & & & & & & & & & 11 & 3 & 3 & 10.0 & {$[0022200000](F)$} \\
\hline Sm 21 & & & & & & & & & & & & & & 12 & 3 & 9 & 30.0 & {$[0477400000](K)$} \\
\hline Sm 20 & & & & & & & & & & & & & & 13 & 3 & 10 & 33.3 & {$[0376710000](\mathrm{I})$} \\
\hline $\mathrm{Sm} 8$ & & & & & & & & & & & & & & \multirow{3}{*}{14} & 3 & 25 & 83.3 & {$[7576734477](U)$} \\
\hline Sm 9 & & & & & & & & & & & & & & & 3 & 25 & 83.3 & [7337713376] (R) \\
\hline Sm 10 & & & & & & & & & & & & & & & 3 & 25 & 83.3 & {$[7777717376](X)$} \\
\hline Sm 45 & & & & & & & & & & & & & & 15 & 3 & 0 & 0 & {$[0000000000](A)$} \\
\hline Sm 5 & & & & & & & & & & & & & & 16 & 4 & 26 & 86.6 & [7376756777] (S) \\
\hline Sm 26 & & & & & & & & & & & & & & 17 & 4 & 3 & 10.0 & {$[0022200000](F)$} \\
\hline $\mathrm{Sm} 3$ & & & & & & & & & & & & & & 18 & 4 & 27 & 90.0 & {$[7776737377](V)$} \\
\hline Sm 19 & & & & & & & & & & & & & & 19 & 4 & 10 & 33.3 & {$[0376510000](\mathrm{H})$} \\
\hline Sm 35 & & & & & & & & & & & & & & \multirow{2}{*}{20} & 4 & 1 & 3.3 & {$[0000200000](B)$} \\
\hline Sm 36 & & & & & & & & & & & & & & & 4 & 1 & 3.3 & {$[0000200000](B)$} \\
\hline Sm 40 & & & & & & & & & & & & & & 21 & 4 & 0 & 0 & {$[0000000000](A)$} \\
\hline Sm15 & & & & & & & & & & & & & & 22 & 5 & 14 & 46.6 & {$[0477645022](\mathrm{L})$} \\
\hline
\end{tabular}


Table 6. cont.

\begin{tabular}{|c|c|c|c|c|c|c|c|c|c|c|c|c|c|c|c|c|}
\hline \multirow[b]{2}{*}{ 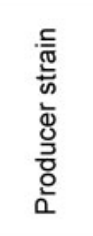 } & \multicolumn{11}{|c|}{ Genotypic profiles based on expressed genes } & \multirow[b]{2}{*}{ 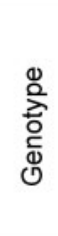 } & \multirow{2}{*}{ 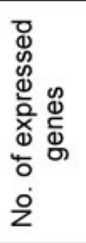 } & \multirow{2}{*}{ 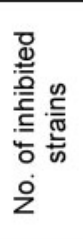 } & \multirow{2}{*}{ 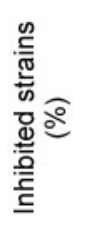 } & \multirow[b]{2}{*}{$\begin{array}{l}\text { Phenotypes based on } \\
\text { mutacin typing }\end{array}$} \\
\hline & $\overline{\mathbb{S}}$ & ฟิ & $\begin{array}{l}\bar{\Xi} \\
\text { ह }\end{array}$ & है & $\stackrel{m}{\underline{E}}$ & 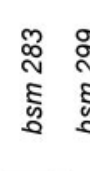 & 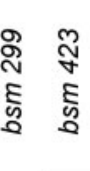 & $\begin{array}{l}\mathscr{D} \\
\stackrel{\infty}{\infty} \\
\stackrel{\infty}{\infty} \\
\text { ह } \\
0\end{array}$ & 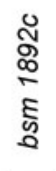 & $\begin{array}{l}\stackrel{\circ}{\circ} \\
\stackrel{\infty}{5} \\
\stackrel{5}{5}\end{array}$ & $\begin{array}{l}\text { ठ } \\
\text { ᄋ } \\
\text { हू } \\
\text { ह }\end{array}$ & & & & & \\
\hline $\mathrm{Sm} 38$ & & & & & & & & & & & & 23 & 5 & 1 & 3.3 & {$[0000200000](B)$} \\
\hline Sm 11 & & & & & & & & & & & & 24 & 6 & 23 & 76.6 & {$[7337613376](Q)$} \\
\hline $\mathrm{Sm} 24$ & & & & & & & & & & & & 25 & 6 & 3 & 10.0 & {$[0002500000](G)$} \\
\hline Sm 25 & & & & & & & & & & & & 26 & 7 & 3 & 10.0 & {$[0006400000](C)$} \\
\hline Sm 29 & & & & & & & & & & & & 27 & 7 & 3 & 10.0 & {$[0006400000](C)$} \\
\hline Sm 30 & & & & & & & & & & & & 28 & 7 & 3 & 10.0 & {$[0006400000](C)$} \\
\hline $\mathrm{Sm} 39$ & & & & & & & & & & & & 28 & 7 & 1 & 3.3 & {$[0000200000](B)$} \\
\hline Sm 28 & & & & & & & & & & & & 29 & 7 & 3 & 10.0 & {$[0006400000](C)$} \\
\hline
\end{tabular}

Streptococcus mutans isolates are independent of the degree of genetic similarity of the strains tested (Table 6). These results may suggest that the genetic and phenotypic traits of mutacin production are related to the genetic background of each isolate tested, or that genetic polymorphisms or other mutacins are as yet unidentified. In addition, the detection of mutacin biosynthesis gene expression in liquid medium (TSB), in comparison with the inhibitory activities of mutacins detected in solid medium (TSA), may have influenced the lack of relationship between genotypic/ phenotypic groupings.

Detailed analysis with purified peptides is necessary to obtain conclusive evidence about the spectrum and role of these antimicrobial proteins. In conclusion, the high diversity of mutacin-producing phenotypes suggests that mutacin production could be an important virulence factor for colonization and establishment of Streptococcus mutans in the oral cavity. Furthermore, the high frequency of expression of the biosynthesis genes screened revealed a broad repertoire of genetic determinants encoding antimicrobial peptides that can act in different combinations; however, more studies are necessary to determine the role of each bacteriocin and to explain how mutacin production is regulated and how mutacins are secreted.

\section{ACKNOWLEDGEMENTS}

This study was supported by CNPq (Grant 140949/04-06), FAPESP (Grant 05/58479-3), FAEP (Grant 1391/2005) and the association of the Minister of Science and Technology of Brazil (MCT), CNPq and FAPESP (Grant 06/60037-1). We thank the Fiocruz Institute for the donation of bacterial strains of medical interest, and Campinas State University (Unicamp).

\section{REFERENCES}

Ajdic, D., McSham, W. M., McLaughlin, R. E., Savić, G., Chang, J., Carson, M. B., Primeaux, C., Tian, R., Kenton, S. \& other authors
(2002). Genome sequence of Streptococcus mutans UA159, a cariogenic dental pathogen. Proc Natl Acad Sci U S A 99, 14434-14439.

Balakrishnan, M., Simmonds, R. S., Kilian, M. \& Tagg, J. R. (2002). Different bacteriocin activities of Streptococcus mutans reflect distinct phylogenetic lineages. J Med Microbiol 51, 941-948.

Bowden, G. H. W. \& Hamilton, I. R. (1998). Survival of oral bacteria. Crit Rev Oral Biol Med 9, 54-85.

Chan, W. C., Dodd, H. M., Horn, N., Maclean, K., Lian, L. Y., Bycroft, B. W., Gasson, M. J. \& Roberts, G. C. K. (1996). Structure-activity relationships in the peptide antibiotic nisin: role of dehydroalanine 5 . Appl Environ Microbiol 62, 2966-2969.

Chia, J. S., Lee, Y. Y., Huang, P. T. \& Chen, J. Y. (2001). Identification of stress-responsive genes in Streptococcus mutans by differential display reverse transcription-PCR. Infect Immun 69, 2493-2501.

CLSI (2006). Methods for Dilution Antimicrobial Susceptibility Tests for Bacteria that grow Aerobically, 7th edn, Approved Standard M7-A7. Wayne, PA: Clinical and Laboratory Standards Institute.

de Vos, W. M., Kuipers, O. P., van der Meer, J. R. \& Siezen, R. J. (1995). Maturation pathway of nisin and other lantibiotics: post-translationally modified antimicrobial peptides exported by Gram-positive bacteria. Mol Microbiol 17, 427-437.

Flório, F. M., Klein, M. I., Pereira, A. C. \& Gonçalves, R. B. (2004). Time of initial acquisition of mutans streptococci by human infants. J Clin Pediatr Dent 28, 303-308.

Hale, J. D. F., Nicolas, C. K., Jack, R. W. \& Tagg, J. R. (2005a). Identification of $n l m \mathrm{TE}$, the locus encoding the $\mathrm{ABC}$ transport system required for export of nonlantibiotic mutacins in Streptococcus mutans. J Bacteriol 187, 5036-5039.

Hale, J. D. F., Tian, T. Y., Jack, R. W., Tagg, J. R. \& Heng, N. C. K. (2005b). Bacteriocin (mutacin) production by Streptococcus mutans genome sequence reference strain UA159: elucidation of the antimicrobial repertoire by genetic dissection. Appl Environ Microbiol 71, 7613-7617.

Hillman, J. D., Novák, J., Sagura, E., Gutierrez, J. A., Brooks, T. A., Crowley, P. J., Hess, M., Azizi, A., Leung, K. P. \& other authors (1998). Genetic and biochemical analysis of Mutacin 1140, a lantibiotic from Streptococcus mutans. Infect Immun 66, 2743-2749.

Kamiya, R. U., Napimoga, M. H., Rosa, R. T., Höfling, J. F. \& Gonçalves, R. B. (2005a). Mutacins production in Streptococcus mutans genotypes isolated from caries-affected and caries-free individuals. Oral Microbiol Immunol 20, 20-24. 
Kamiya, R. U., Napimoga, M. H., Höfling, J. F. \& Gonçalves, R. B. (2005b). Frequency of four different mutacin biosynthesis genes in Streptococcus mutans genotypes isolated from caries-free and cariesactive individuals. J Med Microbiol 54, 599-604.

Klein, M. I., Flório, F. M., Pereira, A. C., Hofling, J. F. \& Gonçalves, R. B. (2004). Longitudinal study of transmission, diversity, and stability of Streptococcus mutans and Streptococcus sobrinus genotypes in children in a Brazilian nursery. J Clin Microbiol 42, 4620-4626.

Kreth, J., Merritt, J., Zhu, L., Shi, W. \& Qi, F. (2006). Cell densityand ComE-dependent expression of a group of mutacin and mutacinlike genes in Streptococcus mutans. FEMS Microbiol Lett 265, 11-17.

Longo, P. L., Mattos-Graner, R. O. \& Mayer, M. P. A. (2003). Determination of mutacin activity and detection of mutA genes in Streptococcus mutans genotypes from caries-free and caries-active children. Oral Microbiol Immunol 18, 144-149.

Napimoga, M. H., Kamiya, R. U., Klein, M. I., Höfling, J. F. \& Gonçalves, R. B. (2005). Transmission, diversity, and virulence factors of Streptococcus mutans genotypes. J Oral Sci 47, 59-64.

Nes, I. F. \& Holo, H. (2000). Class II antimicrobial peptides from lactic acid bacteria. Biopolymers 55, 50-61.

Parrot, M., Caufield, P. W. \& Lavoie, M. C. (1990). Preliminary characterization of four bacteriocins from Streptococcus mutans. Can J Microbiol 36, 123-130.

Qi, F., Chen, P. \& Caufield, P. W. (1999a). Functional analyses of the promoters in the lantibiotic mutacin II biosynthetic locus in Streptococcus mutans. Appl Environ Microbiol 65, 652-658.

Qi, F., Chen, P. \& Caufield, P. W. (1999b). Purification of mutacin III from group III Streptococcus mutans UA787 and genetic analyses of mutacin III biosynthesis genes. Appl Environ Microbiol 65, 3880-3887.
Qi, F., Chen, P. \& Caufield, P. W. (2000). Purification and biochemical characterization of mutacin I from the group I strain of Streptococcus mutans, $\mathrm{CH} 3$, and genetic analysis of mutacin I biosynthesis genes. Appl Environ Microbiol 66, 3221-3229.

Qi, F., Chen, P. \& Caufield, P. W. (2001). The group I strain of Streptococcus mutans, UA140, produces both the lantibiotic mutacin I and nonlantibiotic bacteriocin, mutacin IV. Appl Environ Microbiol 67, 15-21.

Rogers, A. H., van Der Hoeven, J. S. \& Mikx, F. H. M. (1979). Effect of bacteriocin production by Streptoccoccus mutans on the plaque of gnotobiotic rats. Infect Immun 23, 571-576.

Rollema, H. S., Kuipers, O. P., Both, P., de Vos, W. M. \& Siezen, R. J. (1995). Improvement of solubility and stability of the antimicrobial peptide nisin by protein engineering. Appl Environ Microbiol 61, 2873-2878.

Sahl, H. G. \& Bierbaum, G. (1998). Lantibiotics: biosynthesis and biological activities of uniquely modified peptides from Grampositive bacteria. Annu Rev Microbiol 52, 41-79.

van der Ploeg, J. R. (2005). Regulation of bacteriocin production in Streptococcus mutans by the quorum-sensing system required for development of genetic competence. J Bacteriol 187, 3980-3989.

van Loveren, C., Buijs, J. F. \& Ten Cate, J. M. (2000). Similarity of bacteriocin activity profiles of mutans streptococci within the family when the children acquire the strains after the age of 5. Caries Res 34, 481-485.

Wu, C. W., Yin, L. J. \& Jiang, S. T. (2004). Purification and characterization of bacteriocin from Pediococcus pentosaceus ACCEL. J Agric Food Chem 52, 1146-1151.

Yonezawa, H. \& Kuramitsu, H. K. (2005). Genetic analysis of a unique bacteriocin, Smb, produced by Streptococcus mutans GS5. Antimicrob Agents Chemother 49, 541-548. 